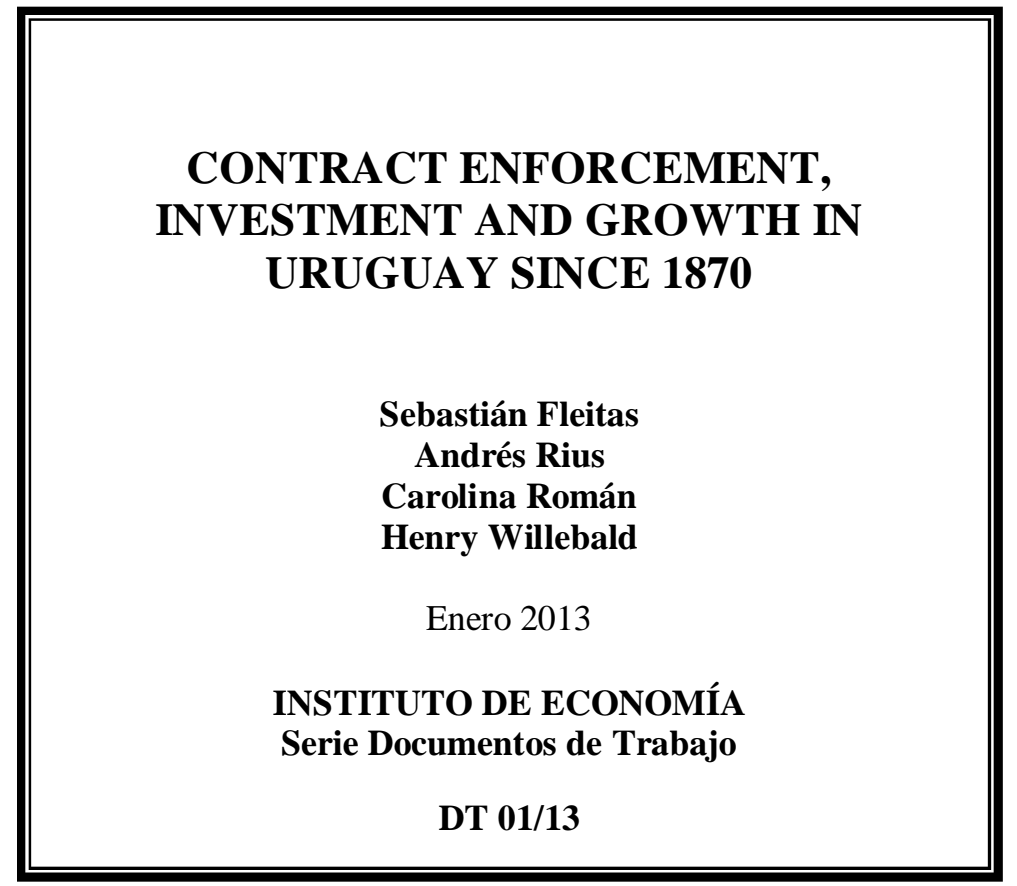

UNIVERSIDAD DE LA REPÚBLICA (UDELAR)- Facultad de ciencias económicas y de administración- Instituto de economía (FCEYA)

URUGUAY

ISSN: 1688-5090 (EN LÍNEA)

ISSN: 1510-9305 (EN PAPEL) 


\title{
CONTRACT ENFORCEMENT, INVESTMENT AND GROWTH IN URUGUAY SINCE 1870
}

\author{
Sebastián Fleitas; Andrés Rius; Carolina Román y Henry Willebald*
}

\begin{abstract}
Institutions and their quality are central concepts in the recent development and institutional economics literatures. Our hypothesis is that inadequate contract enforcement has hindered investment and, in consequence, indirectly has had a negative effect on Uruguay's long-term growth performance. We first review the main concepts and the approaches to define and measure the quality of contract enforcement. We then introduce one measure that has the advantages of being measurable into the past and not depending on subjective judgments; namely, the "contract intensive money" (CIM) indicator proposed by Clague et al. (1999). Using our long series for the CIM indicator, and extending key macroeconomic variables backwards to 1870 , we are able to estimate a structural model to explore the plausibility of our hypothesis. In the estimation, based on the seemingly unrelated regressions (SUR) method, we find support for the thesis that the quality of contract enforcement influences growth through its impact on investment. Put differently, our results suggest that poor contract enforcement played a significant role at the root of Uruguay's underperformance, and in its experience of (relative) long-run decline.
\end{abstract}

Keywords: Contract Enforcement, Contract intensive money, investment, Uruguay

JEL: N16, N26, N46, O43

1 We thanks the financial support from the Project "Instituciones e Inversión en el Uruguay", Universidad de la República-CSIC, Programa I+D. Early versions of this article were presented at the XXVI Jornadas Anuales de Economía, Banco Central del Uruguay (August, 2011); II Jornadas Académicas, Facultad de Ciencias Económicas y de Administración, Universidad de la República (UdelaR) (September, 2011); Seminario de Investigación del Programa de Historia Económica y Social, Facultad de Ciencias Sociales, UdelaR (October, 2011); 5tas Jornadas de Historia Económica, Asociación Uruguaya de Historia Económica (AUDHE) (November, 2011); Seminario Estrategias de desarrollo frente a la crisis, Departamento de Economía, Facultad de Ciencias Sociales, UdelaR (December, 2011). We are grateful for the many comments received and specially to Diego Aboal, Verónica Amarante, Paola Azar, Luis Bértola, Elizabeth Bucacos, Gabriel Burdín, Rafael Laureiro, Gabriela Mordecki and María Inés Moraes. We thanks Prof. Leandro Prados de la Escosura (Universidad Carlos III de Madrid) and Isabel SanzVillarroya (Universidad de Zaragoza) for generously sharing their data for Argentina, Australia and Canada. We are also solely responsible for any remaining errors.

* Instituto de Economía, Facultad de Ciencias Económicas y de Administración, Universidad de la República. E-mails: sefle@iecon.ccee.edu.uy; arius@iecon.ccee.edu.uy; croman@iecon.ccee.edu.uy; hwillebald@iecon.ccee.edu.uy 


\section{Introduction}

Uruguay is a small "settler" economy in the Southern Cone of South America, often compared with New Zealand for their resemblance in terms of settlement pattern, productive structure and size. By the last quarter of the $19^{\text {th }}$ century, Uruguay had a greater per capita GDP than Finland (more than double) and a similar level to Denmark's. In the first years of the $21^{\text {st }}$ century, its per capita GDP was about a third of Denmark's or Finland's ${ }^{2}$.

Not surprisingly, institutionalist accounts of Uruguay's long-run performance have proliferated in the last two decades, following the growth of the New Institutional Economics, after Douglass North's books and articles and his accession to the Nobel Prize in Economics. A regularity of the literature on Uruguay's development trajectory is that many of the contributions rely on a single indicator of the "quality of institutions". Tacitly or explicitly, this means that in the eyes of the observers the distance between the observed and some "high quality" institutions is what drives the growth of incomes. This article represents a step towards greater specificity in the study of institutions and results in Uruguay, in the "long $20^{\text {th }}$ century" (between the last quarter of the $19^{\text {th }}$ century and the first decade of the $21^{\text {st }}$ ).

Our hypothesis is that the quality of contract enforcement is a key determinant in the process of economic growth, and that it affects growth indirectly through its effects on investment. To study such hypothesis systematically, we build a dataset containing time series of the variables that are most frequently found in recent growth empirics. This, by itself, is a contribution of the article, as series for such a long period were not available until now. We measure the effectiveness of contract enforcement using the one indicator that can be estimated for lengthy time spans; i.e., the Contract Intensive Money (CIM) index developed originally by Clague et al. (1999) and applied successfully by themselves and others, to address various questions on institutions and the economy (Pang and Wu, 2009; Prados de la Escosura and Sanz, 2009). Our analysis mirrors the one undertaken by Prados de la Escosura and Sanz (2006, 2009) for Argentina, thus shedding light not only on another country studied with the CIM indicator but also on the similarities and differences between two highly interconnected economies of South America.

The organization of the article is as follows. After discussing the institutionalist development literature on Uruguay, we present our analytical framework and justify the focus on contract enforcement. Then we present and compute the CIM indicator. We examine the CIM's and other long term series (from 1870 to 2010) and discuss them in light of the prevailing interpretations about development and institutions in Uruguay, and of the comparison with Argentina. We find that the trajectory of the indicator matches the informed intuitions and some scholarly work about stages in Uruguay's long run institutional evolution. Following that, we perform a series of econometric exercises to explore further the hypothesis that the quality of contract enforcement is associated with the rates of capital accumulation and, in consequence, with economic

\footnotetext{
${ }^{2}$ Calculations based on per capita GDP in 1990 Geary-Khamis from Maddison (2003). See Álvarez and Bértola (2012) and Willebald and Bértola (2012) who review recent comparative studies about settler economies.
} 
growth, even when relevant controls are included in the analysis. The estimations, based on the "seemingly unrelated regressions" method (SUR), suggest that poor contract enforcement played a significant role at the origins of Uruguay's long-run decline.

\section{Background and conceptual framework}

\subsection{Institutional explanations of Uruguay's long-run performance}

In the field of economic history, there has been an increasing interest in institutional theories of economic performance. Part of the recent literature is based on analytical descriptions of the institutional configurations while others introduce (some quantitative measures of) the institutions in the empirical study of aggregate performance. The scholarship on Uruguay's trajectory since the $19^{\text {th }}$ century also follows this pattern. Below are some salient and representative examples of those approaches.

From a very long term perspective, Bértola and Porcile (2000) made some first attempts to introduce the role of institutions within a convergence and divergence framework, comparing the Southern Cone's performance with that of the World's core economies. Another group of articles has studied the role of institutions mainly focused on the description of the land property system, especially in the agrarian sector. On the one hand, Álvarez, Bértola and Porcile (2007) contains several articles that introduce the impact of the land property system in the discussion about growth and income distribution during the First Globalization, comparing the experiences of Uruguay and Argentina with Australia and New Zealand. With a similar approach, Alvarez et al. (2010) and Álvarez and Willebald (2011) go deeper in a systematic description of the agrarian land ownership system. They identify some specific features of the River Plate region, contrasted with the Australasian economies that may explain the worse performance of the first group in the long run.

Willebald (2011) is the most direct antecedent of the current article. The author introduces the CIM indicator as an overall index of the quality of institution, to explain, among others, the diverse development process of the settler economies during the First Globalization. Siniscalchi (2010) is another effort to assess the effect of the quality of institutions on Uruguay's long run performance, but focused on the institutions constraining government. Finally, Zurbriggen (2006) continues down a pathway started by Rama $(1990,1991)$ and proposes a political institutional approach to explain the effects of rent-seeking behavior during the period of "state led industrialization".

Oddone (2010) is another recent attempt to explain Uruguay's performance over more than a century giving a prominent role to "institutions". The definition of "institutions" used is broad, while the empirical exercises point to a central concern with the "political rules" about who decides what and when or under what constraints. However, the author does refer to property rights and contract enforcement institutions, even if he does not attempt to reflect them explicitly in the empirical study (citing the lack of appropriate indicators covering a long enough time span). He also seems less interested in those factors, apparently because of the priority given to the broader concepts of "discretion" and "rules" to characterize the exercise of power by governments (p. 179). 
Interestingly enough, the "rules vs. discretion" debate had had an earlier and somewhat atypical expression in another widely cited study; that is Rama (1990). Analyzing mainly the last two thirds of the $20^{\text {th }}$ century, Rama had argued that Uruguay had done best when the governments had been effectively isolated from the pressures of interest group. Those pressures would translate in various forms of overt or hidden patronage, and tailor-made policies to favor specific groups or even specific companies. This "patronage cum rent-seeking" explanation, which was more systematically examined in other contributions by the same author, could be understood as a weakening of the rule of law, and eventually disrespect for contracts. What is worth noting is that, in Rama, it is government "discretion" that favors economic growth rather than "rules" (perhaps because the former is assumed to be put to constructive use when available, while the latter are too often interest-group oriented).

Perhaps the study that goes deeper into the theoretical and empirical complications in the protection of property rights and enforcement of contracts, in the Uruguayan context, is Bergara and Zipitría (2003), and its predecessor Zipitría (2001). While the authors do not adopt a long term perspective, and rather focus on providing an account for the observed (contemporaneous) weak protection of investor's rights and contracts, they are the ones that most decidedly point to those factors as crucial to understanding the country's performance. The cited works focus on bankruptcy law and explaining its ineffectiveness more than exploring empirically its consequences. The lead author (Bergara) explores other institutional features of the country in the cited volume, generally with an important amount of detail about specific formal arrangements. Yet, they rightly point out more generally that formal rules alone cannot account for the weakness of those institutions, and that the effects of the law must be understood in a broader institutional context.

\subsection{Conceptual framework}

Even if development is defined to be broader than economic growth, there are still some very good reasons to consider that growth is one of development's key components and the means to attain other valuable ends (Sen 1999). In turn, investment to increase or maintain a functioning stock of productive assets is at least one condition for sustained growth. While some authors have questioned the usual assumption about investment being a driver of growth (see, e.g., Dollar and Easterly 1999; Devarajan, Easterly and Pack 2001), the evidence is not conclusive enough to treat investment variations as merely a consequence of the growth process.

In recent years, institutions have become more prominent among the factors that might determine growth and investment (Rodrik 2000; Shirley 2008). However, there has been some disagreement about their relative role vis-à-vis of other factors such as natural resource endowment and a country's place in the global geography. Moreover, institutions have been found to be too broad a term, needing further specification of its contents and of the ways in which it might influence asset accumulation and economic growth. In particular, Acemoglu and Johnson (2005) have persuasively argued that contracting institutions should be distinguished from property rights institutions, when it comes to elucidating how (certain) institutions affect economic performance. It is in 
this spirit that we examine a narrow set of institutions: those that make contracts more reliable or easier to enforce, and we narrow down that concept even further, approximating enforcement efficacy through a single country-wide and time-variant indicator of confidence in contracts between banks and their clients.

The seminal works on institutions and economic performance still influence the discipline's understanding about the channels through which variation in the effectiveness of contracts would be felt in levels of investment and growth. North (1990) points out that it is the growing complexity of economic transactions that raises the need for more formal (written) contracts, stipulating the parties' rights and responsibilities, and for "external" (that is, third-party) adjudication and enforcement. While in principle (and in some real-world situations) transactions may be carried out on the basis of "gentlemen's agreements", without the need for third-party intervention to resolve disputes, the growing dislocation of economic exchanges (in time and space) makes written and externally-enforced contracts a necessity.

Breaches of contracts can be quite deleterious to investment and growth. They can encourage "hold-up" behavior (or non-compliance by a contracting party that was expected to supply an input or pay for a service). When this happens frequently, firms may be forced to procure from less efficient suppliers, or to adjust their desired investments downward to manage risks (Cungu and Swinnen, 2003), or they may be induced to keep inefficiently high inventories (a case of an undesired higher "investment"; Raja and Schaefer 2007). ${ }^{3}$ More frequently noted, if banks fear that they will be unable to recover loans, they will be hesitant to lend and investments requiring external, bank financing may be hindered (Levine 1998). Monge-Naranjo (2009) has argued that through financial contracts, imperfect enforcement can influence the size distribution and heterogeneity of firms. Contract uncertainty may be more deleterious for investments such as those in research and development activities that have a greater inherent uncertainty or longer maturity times (Clarke 2001; Lin, Lin and Song 2010). The latter could explain why many developing countries fail to build functional innovation systems.

As seen above, there have been several institutionalist interpretations of Uruguay's long-term underperformance, and particularly of its lagging position in the post World War II global economy. We propose to test the hypothesis that flaws in the institutional arrangements that determine the reliability of economic contracts have something to do with such poor performance.

\subsection{Measuring the quality of enforcement}

The last two decades have seen efforts to generate indicators and proxies to test a variety of hypotheses about institutions and aggregate performance (see, e.g., Knack and Keefer 1995; Kaufman et al. 2004; Williams and Siddique 2008). At the same time, the proliferation of databases that include measures of institutional arrangements have also stimulated the generation and empirical investigation of new research questions (but also, sometimes, "data-driven" research has not shed much light on the causal mechanisms of interest; Aaron 2000; Keefer 2004; Pande and Udry 2005).

\footnotetext{
${ }^{3}$ All the references in this paragraph come from Aboal et al. (2011), and refer to studies that test a complete causal chain from quality of enforcement to investment rates/levels.
} 
As mentioned above, the enforcement of contracts can be "private" (Hamish et al. 2000). In these cases, it tends to be informal and could be affected by reforms to the formal enforcement mechanisms, but also by other policy reforms (as, e.g., in Woodruf 1998). That said, at least since the consolidation of large nation-states, national and subnational jurisdictions have had some form of third-party, formal adjudication mechanism, and that is why quality of contract enforcement is usually taken to be an attribute of those political entities (Djankov et al. 2003; Acemoglu and Johnson 2005). For those reasons, the quantitative operationalization of quality or effectiveness of contract enforcement has largely been done through indicators that rate such quality for national jurisdictions at given points in time (in other words, the sources and methods typically give place to a "country-time" observations matrix).

Four broad approaches have been followed to generate cross-section and longitudinal variation in those indicators. In roughly chronological order, they are:

(i) Experts' assessment: effectiveness, efficiency and/or fairness of the formal enforcement mechanism is assessed by practitioners and other key informants, and conveyed and aggregated through survey methods (Knack and Keefer 1995; but also La Porta et al. 1997, and Berkowitz et al. 2003; Staats et al. 2000). Since several of these have been carried out by investor advisory companies for some time, these indicators often provide a diachronical perspective spanning about four decades for major or more developed countries, and shorter periods for others. Regarding the enforcementinvestment link, Banerjee et al. (2006) are an example of the application of this strategy, using the "rule of law" indicator of the International Country Risk Guide dataset in a pooled cross section analysis. ${ }^{4}$

(ii) Indirect measures based on "objective" data, such as the estimated use of "contractintensive money". This is the strategy that is favored in this article, and probably the only one that can retrospectively generate really long time-series on quality of institutions. Clague et al. (1999) developed this approach, assessed the validity of the indicator, and tested empirically the enforcement-investment connection.

(iii) Surveys of real economic agents, in which questions about contract enforcement and protection of investors' rights are asked to those that most directly bear their effects (Brunetti et al. 1997; Dao 2008), along with economic performance and other possible conditioning variables). These have the advantage of eventually leading to the generation of pooled cross-sections of firms, if not proper panels; but suffer from the same limitation of inconveniently short time spans.

(iv) Quantification of time and pecuniary costs to enforce standard contracts. In these cases, it is legal experts that are asked to estimate the time and financial costs incurred by a private party to get his/her rights established when facing breach of contracts (the contracts chosen to generate the measure are typically simple and present in almost any market or mixed economy, such as, e.g., failure to cash a bounced check, or the eviction of a delinquent tenant; Djankov et al. 2003). ${ }^{5}$ This approach has the advantage of relying in more "objective" basic data, but it has to take jurisdictions as the unit of analysis (not economic agents) and it has not yet been implemented to record variations over time. Acemoglu and Johnson (2005) use these datasets to test the enforcement (vs. property rights) hypotheses regarding investment and growth.

\footnotetext{
${ }^{4}$ See ICRG http://www.prsgroup.com/ICRG.aspx.

${ }^{5}$ Djankov et al. (2008) have estimated the more complex legal implications of getting redress regarding a bank loan.
} 
A significant body of research has focused on exploiting these data sets and the variations over space and time of institutional factors and economic outcomes. This explains why most of the studies in the literature are cross-section, panel or longitudinal analysis, for countries, firms or sub-national jurisdictions as the units of analysis (see Aboal et al. 2012). ${ }^{6}$

\section{4. "Contract Intensive Money" and the long term analysis of institutions and performance}

While there are good reasons to go beyond these readily available data sets (see the persuasive arguments in Pande and Udry 2005; also Rehme 2007; Rodrik 2005), we are of the view that there is still value in extending the reach of studies undertaken with existing datasets and methods. ${ }^{7}$ This paper extends the "indirect measures" strategy, by using the "contract- intensive money" (or CIM) indicator to study more than a century of a single country's history. The value added of the article derives from (a) the use of a historical lens to analyze what the indicator supposedly shows about quality of specific institutions, (b) the "pull" effect it is having on work to estimate longer-term investment data (to pair it up with farther-reaching monetary indicators), and (c) a conscious discussion of the econometric findings, looking as much for analytically interesting results as well as for lessons on methods and their potential limitations.

Clague et al. (1999, p.187) argue that the government has four crucial roles to play in contract enforcement and the protection of property rights: (i) it provides third-party enforcement when no self-enforcing mechanism exists; (ii) it may be the source of information about branches of contracts; (iii) it may enforce the arrangement that private agents devise to constitute themselves as a formal group and thus "self-enforce" contracts; and (iv) it guarantees internal peace, preventing agents for acting as in a Hobbesian anarchy. These functions would be valuable in a variety of historical settings. The authors then argue that, to capture the effectiveness of contract enforcement through time, it is possible to use the societies' reliance on non-currency money, since such "means of payment" and "reserves of value" would not be chosen by agents that are skeptic about the government's willingness or capacity to enforce contracts.

The application of those ideas to developing economies is not new. Prados de la Escosura and Sanz-Villarroya $(2006,2009)$ use the same concept to evaluate the role of institutional arrangements in the long-run decline of Argentina, comparing the evolution of its CIM values with those for Australia and Canada. Both, Clague et al. (1999) and Prados de la Escosura and Sanz-Villarroya (2009), persuasively demonstrate the validity of the indicator. The former conclude that "CIM is a reflection or measure of the type of governance that improves economic performance rather than a cause of that performance"(Clague et al. 1999, p. 189).

\footnotetext{
6 There is also an extensive literature on the economic consequences of different governance, political, law-making, civil rights institutions, which we do not explore here. For a useful review see Pande and Udry (2005) and Shirley (2008).

7 One of the main conclusions of the systematic review by Aboal et al. (2012) is that the empirical base on the link between contract enforcement and investment is extremely thin for a policy relevant question.
} 
The main advantages of the CIM indicator as a measure of quality of contract enforcement, and more generally as a proxy for institutional quality, are that (i) it relies on secondary quantitative measures that are not likely to be influenced (biased) by any expert group's subjective assessment of how institutions worked or are working in any particular setting, and (ii) with

careful economic-historical effort, one can build rather long series for the indicator. There are, however, some potential downsides that must be acknowledged. On one hand, it can arguably be a reflection, for longer or shorter periods, of depth (or repression) of the financial system, for reasons unrelated to the respect of contracts, and it can reflect perhaps too directly the effects of changes in macroeconomic conditions even while the quality of contracting institutions remain unchanged (Williams and Siddique 2008). Nonetheless, we believe that the pros are significant enough to merit its further investigation.

\section{Data, long run overview and econometric exercises}

\subsection{Data and sources}

Following a similar strategy than Clague et al. (1999) and Prados de la Escosura \& Sanz $(2006,2009)$ we proceed in two steps: we offer a historical description of the evolution of the series and an exercise of estimation where we employ the seemingly unrelated regression method (SUR). Econometric exercises require long series that are typically not available in the national statistical system, so we generated original estimates of CIM, capital stock and other variables, for the period 1870-2010. ${ }^{8}$ As the indicators of CIM and capital accumulation (investment) are of main interest for our analysis, we will briefly describe their construction (the sources and transformations/calculations for other variables in the study are described in the Appendix).

With Clague et al. (1999), we define contract-intensive money (CIM) as the ratio of non currency money to total money supply, or (M2-C)/M2, where M2 is a broad definition of money supply and $\mathrm{C}$ is currency held outside banks. The CIM indicator was taken from Román and Willebald (2011), who proceeded in the following way.

Different sources were used to calculate the currency in circulation. From 1912 onwards, the currency in circulation was taken from Banco Central del Uruguay (1971; and on-line data available at http://www.bcu.gub.uy); for 1900-1911 the series were estimated on the basis of the variation of total emission published in Banco Central del Uruguay (1971). For the period before 1900 the estimations relied on the data about total emission reported in Acevedo $(1933,1934)$ and Arocena and Graziani (1987). For the years with missing data $(1877,1878,1879$ and 1881) the estimations are lineal interpolations.

Diverse sources were also considered for the estimation of deposits. For the post-1912 period, there is data on total deposits from Banco Central del Uruguay (1971; and on-line data) calculated as money supply less currency. For the previous period there is a lack of

\footnotetext{
${ }^{8}$ Details about the methodology and data sources used to estimate the CIM (1870-2010) and the investment (1870-1954; from 1955 to the present we consider official estimates) are described in Román and Willebald (2011).
} 
systematic information on total deposits in the bank system. For 1903-1911 the estimation was based on the yearly change in total deposits at Banco de la República (previous to the creation of Banco Central del Uruguay); for 1888-1903 the series is based on the variation of the deposits in all banks reported in the Statistical Yearbooks (several years). For the years 1883-1887, 1870-1874 and 1869 the variation of deposits in the emission banks reported in Acevedo (1933) were the sources applied. The gaps in the data $(1870,1875-$ 1882) were filled with lineal interpolations.

The series of physical capital stock are taken from Román and Willebald (2012) based on the Perpetual Inventory Method (PIM), which is one of the most widely used estimation procedures in the literature (World Bank 2011; Prados de la Escosura and Rosés 2008). This method uses cumulative investment series -in our case, the gross fixed capital formation at constant prices- and estimates of the assets' service life and depreciation cycle. In the paper, Román and Willebald (2012) follow the criteria used by the World Bank $(2006,2011)$ and assume a geometric depreciation pattern with a 5 percent depreciation rate and 20 years of service life. To check the sensitivity of results to this assumption, the estimations were repeated with another depreciation rate $(8$ per cent) and the main results do not change. ${ }^{9}$

\subsection{Growth, capital accumulation and contract enforcement: historical trajectories}

We first discuss the economic evolution of Uruguay in the long run -from the last decades of the $19^{\text {th }}$ century to 2010 - in terms of GDP, productive structure, capital accumulation and institutions. This historical overview allows us to identify some stylized facts that provide a historical context to our econometric work.

In the long-run, Uruguay exhibits an irregular trajectory that alternates periods of important productive expansion with others of deep depressions. Figure 1 presents the evolution of total GDP from 1870 to 2010 (in thousands of Uruguayan pesos of 2005). Traditionally, local historiography (see Bértola 2008; Oddone 2010; Willebald 2006) recognizes three phases associated with different "development patterns". From the last quarter of the $19^{\text {th }}$ century to the 1920 s, the economy experienced a significant exportled growth, based on a few primary products, and it obtained welfare levels close to the core countries of the international economy. ${ }^{10}$ The Great Depression meant severe negative effects on the open economy and the meager performance lasted until the middle of the 1930s (Jacob 1977, 1981). After the Second World War (WWII), the economy presented a second period of steady economic growth characterized by an increasing participation of the state in the economy (Azar et al. 2009), an improving income distribution (Bértola et al. 2000; Bértola 2005) and a (truncated) process of import substitution industrialization (ISI) (Arnábal et al. 2011; Bértola 1991; Finch 2005). However, the positive evolution was mostly exhausted by the end of the 1950s, and the economy entered in a long period of "stagflation" that lasted until the beginning of the 1970s (Astori 2001). During the first half of the 1970s, in a context of deep social and political changes, the economy experienced important adjustments that became a new development pattern (Notaro 1984, 2001). Increasing trade openness, financial

\footnotetext{
${ }^{9}$ Noya et al. (2003) used a 8 percent depreciation rate to calculate the aggregate capital stock in Uruguay for the period 1940-1999.

10 According to Maddison (2003) in 1913 Uruguay was among the top-20 countries in the global per capita GDP ranking (see Bértola and Porcile 2000; Willebald 2007).
} 
liberalization, and new regional trade agreements gave place to a new phase of economic expansion that extended until the end of the $20^{\text {th }}$ century and that some authors identify with a "re-globalization" period (Oddone 2010). The begging of $21^{\text {st }}$ century was dominated by one of the deepest crisis of the last one hundred years and, since 2003 , the economy recovered strongly with a firm presence in the international markets of commodities and important changes in the organization of primary production (Errea et al. 2011). What type of implications did this long-run performance have in terms of the structural change of the economy?

Figure 1

Gross Domestic Product (logarithm scale) (2005 thousands of Uruguayan pesos)

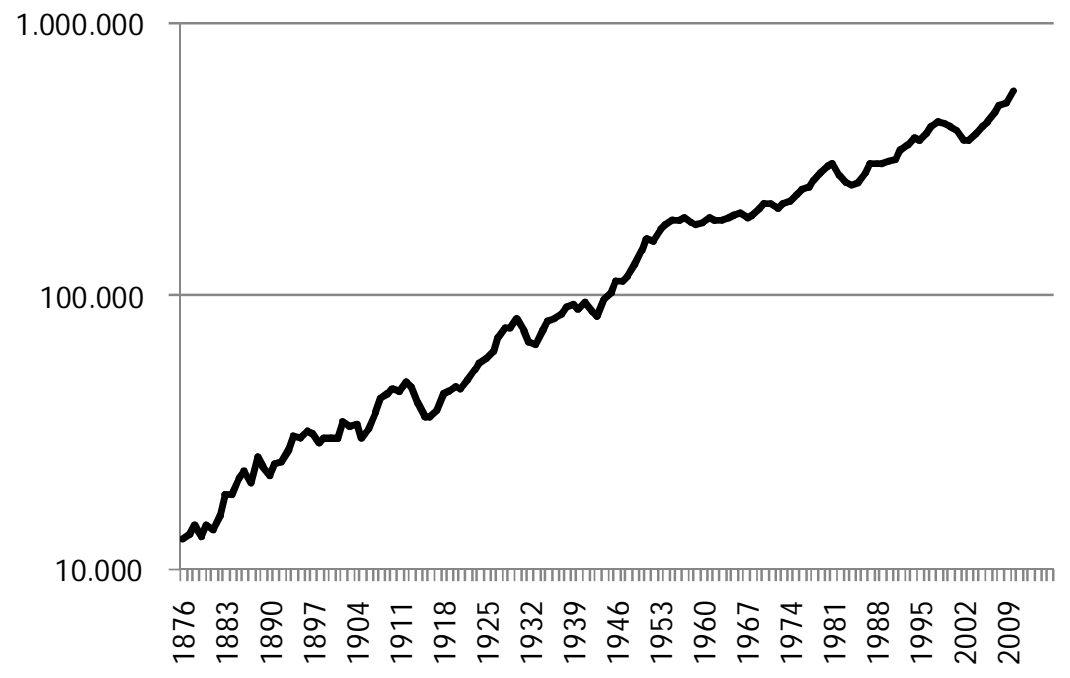

GDP (2005 constant prices) (thousand of pesos)

Source: See Appendix.

Following a previous study (Bonino et al. 2012) we consider three large productive sectors -agriculture (crops and cattle), industrial (manufacturing and construction) and services (the rest of the economic activities) - and describe the trajectory of the sector contributions to GDP (our measure of structural change). Figure 2 shows the evolution from the last decades of the $19^{\text {th }}$ century to the begging of the $21^{\text {st }}$ century. 
Figure 2

Sector contributions to GDP (share on current GDP)

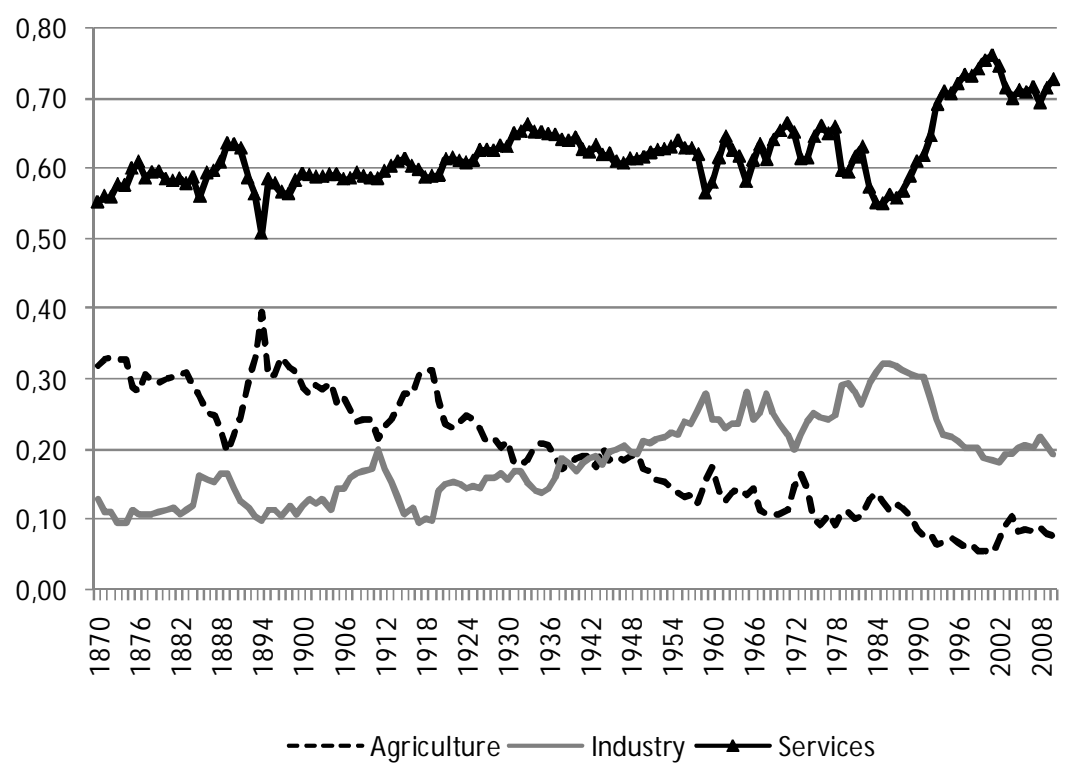

Source: Bonino, et al. (2012).

The historical characterization of Uruguay as an agrarian economy since the $19^{\text {th }}$ century is essentially based on the type of integration in the international commodities markets (with exports of primary products such as jerky, leather, wool and beef). However, this type of agrarian trade specialization required the extended presence of activities that supported the commercialization of these products such as transport and storage, logistic, financial and professional services, and public services. In addition, Uruguay experienced a dynamic urbanization process that rapidly brought the administrative capital of the country, Montevideo, to the head of a macro cephalic country. ${ }^{11}$ Under these conditions, it is not surprising that the share of services in GDP was around 55 per cent during the period of export-led growth. As it was expected, the ISI process meant a sustained and progressive increase of the industrial activities and manufacturing became the leading sector during the following decades. In contrast, agriculture systematically lost participation. Despite these changes in the "material production" of the economy, the service sector maintained a stable share of GDP around 60 per cent until the 1980s. Since this decade, this group of activities has increased its participation in GDP while the manufacturing sector diminished it (Antía 2005). ${ }^{12}$ Within this context, our CIM indicator provides interesting insights (Figure 3).

\footnotetext{
${ }^{11}$ In 1930, 81 per cent of the total population lived in cities and 32 per cent in Montevideo (Nahum 2007, Table A.1.5, p. 14).

${ }^{12}$ Some authors identify these decades with a deindustrialization period (Bittencourt and Bértola 2005).
} 
Figure 3

Contract Intensive Money (CIM) Indicator

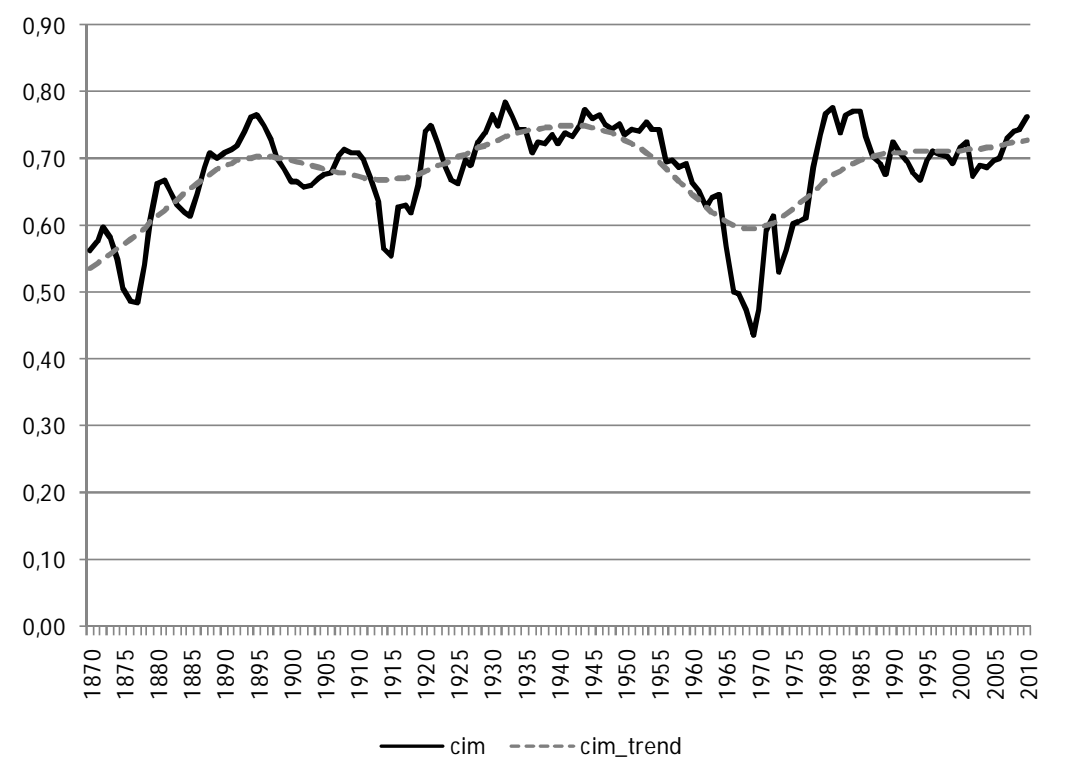

Source: See Appendix.

From a visual inspection of the series we identify a three-arch-shape evolution that, grosso modo, coincides with the three phases of Uruguayan development. The "volatility" of the early trajectory ${ }^{13}$ and the absence of a definite trend coincide with a period of high institutional instability, when internal conflicts and a weak central government characterized the Uruguayan economy until, at least, the first decade of the $20^{\text {th }}$ century (Nahum 1993). These dynamics changed after the First World War (WWI). CIM increased towards the beginning of the 1930s, when it declined reflecting the instability associated with a deep depression and the first military dictatorship of the $20^{\text {th }}$ century led by President Gabriel Terra (Jacob 1983). Since the 1940s, the indicator maintained a relative stable level through the $1950 \mathrm{~s}$, which is consistent with a stable sociopolitical context, with a consolidated democracy and a relatively large welfare state. However, the increasing political and social instability of the $1960 \mathrm{~s}$, together with a trend toward informal financial intermediation that meant net disintermediation (Vaz 1999), initiated a deep downward trajectory of the CIM indicator until the end of the decade.

During the next ten years, CIM recovered in a context characterized by important political changes, new macroeconomic strategies (exchange rate based stabilization; reduction in import restrictions; removal of causes of financial repression; and low prudential regulation and supervision in the banking system). In that period, CIM approached the levels of the 1940s. However, it fell again in the early 1980s in an environment of high uncertainty associated to the severe financial and external debt crisis of the period (Antía 1986; Vaz 1999), and the collapse of the fixed exchange rate. $^{14}$ After this negative shock, the trajectory was relatively stable until 2006, and

\footnotetext{
${ }^{13}$ See Willebald (2011) for a comparison with settler economies.

${ }^{14}$ The average depreciation of "peso uruguayo" between 1982 and 1983 was almost 150 per cent.
} 
since 2007 the ratio has increased in a period of macroeconomic stability and positive social indicators. At first sight, our indicator seems to follow a plausible path, considering the broad-brush socio-political and economic scenarios of the last one hundred and forty years.

However, are these evolution and levels consistent in a comparative approach? In Table 1 we present decennial averages of CIM values for Uruguay, Argentina, Australia and Canada, as a way to compare different long-run institutional performances. Two stylized facts are clearly identified. On the one hand (and as it is observed by Prados de la Escosura and Sanz 2009), Australia and Canada improved their respective quality of contract enforcement rapidly and early in the $20^{\text {th }}$ century. On the other hand, Argentina and Uruguay showed similar evolutions that seem to reflect the "family ties" of their respective historical trajectories, but contain also some specificities. While the CIM was growing slowly on average, in Argentina for the last three decades of the 19 century, it was quickly moving upwards in Uruguay, which ended the century with an average closer to Canada's than to its neighbor. With the new century, Argentina's values kept rising slowly until the second decade of the $20^{\text {th }}$ century, and ended that upwards drive very close to Canada's, while Uruguay's moved erratically close to the 0.7 point. Argentina then would have started a decline in the effectiveness of contract enforcement which appears to have lasted until the 1960s, while Uruguay continued the oscillating trajectory but hit a century's minimum in the 1960s (slightly above the 1870s average). In the two countries the scores moved up in the 1970s and 1980s, and slightly down in the 1990s and 2000s. It appears that, on average, contract enforcement was slightly better in the decades of military coups and debt crisis than in the two following decades of democratic rule and new economic crisis.

Table 1. CIM Indicators (decennial averages)

\begin{tabular}{|c|c|c|c|c|}
\hline & Argentina & Australia & Canada & Uruguay \\
\hline $1870-1879$ & 0.523 & 0.845 & 0.662 & 0.550 \\
\hline 1880-1889 & 0.573 & 0.897 & 0.724 & 0.659 \\
\hline $1890-1899$ & 0.582 & 0.916 & 0.820 & 0.728 \\
\hline 1900-1909 & 0.676 & 0.923 & 0.865 & 0.681 \\
\hline 1910-1919 & 0.774 & 0.938 & 0.884 & 0.638 \\
\hline $1920-1929$ & 0.832 & 0.938 & 0.897 & 0.709 \\
\hline 1930-1839 & 0.802 & 0.941 & 0.911 & 0.745 \\
\hline 1940-1949 & 0.748 & 0.881 & 0.846 & 0.750 \\
\hline 1950-1959 & 0.606 & 0.881 & 0.855 & 0.724 \\
\hline 1960-1969 & 0.617 & 0.911 & 0.883 & 0.572 \\
\hline 1970-1979 & 0.764 & 0.913 & 0.909 & 0.603 \\
\hline 1980-1989 & 0.805 & 0.913 & 0.932 & 0.740 \\
\hline 1990-1999 & 0.787 & 0.936 & 0.940 & 0.700 \\
\hline
\end{tabular}




\begin{tabular}{|l|l|l|l|l|}
\hline $2000-2009$ & 0.772 & 0.952 & 0.948 & 0.712 \\
\hline
\end{tabular}

Source: Data for Argentina, Canada and Australia belongs to Prados de la Escosura and Sanz (2009) and was generously provided by the authors. Uruguayan's data is from Román and Willebald (2011).

What happened to capital accumulation in historical perspective? As a capitalist economy that abandoned early the subsistence stages, ${ }^{15}$ capital stock increased significantly in the long-run (Figure 4). From the beginning of the period to the 1910s, the series present an in step evolution that reflects the pattern of investment. During this period, the driving forces of capital accumulation were infrastructure and transport investments (railways, trolley cars, bridges, ports), that meant large funds applied intermittently and in few years. Afterwards, the increasing trajectory presented a stable evolution with some periods of slowing down.

Figure 4

Capital stock (logarithm scale) (thousand 2005 Uruguayan pesos)

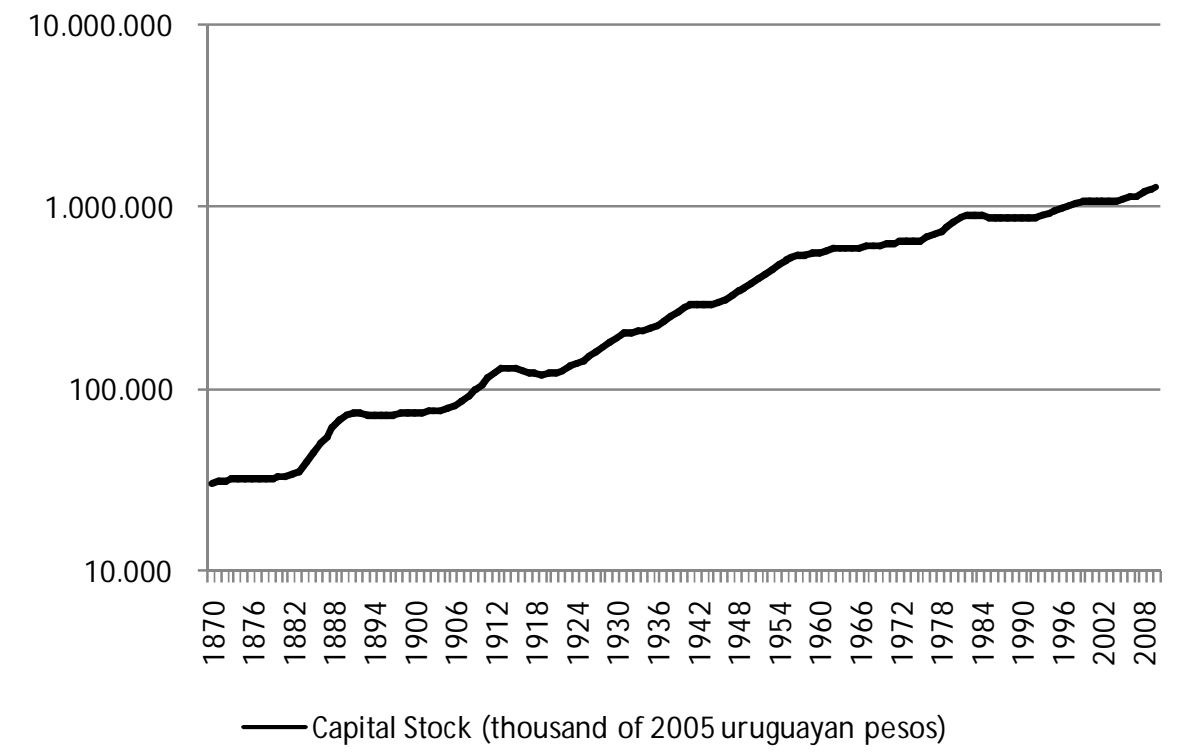

Source: See Appendix.

The evolution of the fixed investment rate -defined as the ratio of gross investment to GDP-was highly volatile and without clear trends (Figure 5). ${ }^{16}$ In the long run (18702010), the average rate was 14 per cent although this ratio was not representative of the historical performance. In the $1870 \mathrm{~s}$, the investment rate declined but, in the second half of the 1880s, the economy experienced the first boom of the construction industry that resulted in investment rates above 25 per cent. This boom finished with the 1890's crisis, a critical period characterized by bankruptcies and a general recession (Visca

\footnotetext{
${ }^{15}$ According to Maddison's criterion, the subsistence levels correspond to incomes per capita around \$ 400 (in 1990 prices). The income per capita of Uruguay in 1870 is 5.5 times Madison's threshold.

${ }^{16}$ See Román and Willebald (2012) for data presentation and the analysis of the evolution of investment in the long run.
} 
1967). Afterwards, the investment recovered, first slowly during the second half of the 1890s and then quickly from 1904, during a period of strong economic growth and a new expansion of the infrastructures that stopped abruptly with WWI.

The 1920s were years of recovery in several spheres of the economy (Bertino et al. 2001), and physical capital accumulation followed this process achieving investment rate levels between 15 and 20 per cent. However, the Great Depression represented another strong negative shock, and the investment rate went down to close to 10 per cent in 1935. It recovered in the second half of the 1930s, although WWII meant a new break in the evolution. Since 1945, and probably determined by the ISI process that dominated the economy during the 1940s-1950s, fixed investments recovered and averaged 16 per cent until the end of the decade. This was a period of relatively high investment rates (in historical perspective) but it did not mean a real "capital boom". The industrialization of Uruguay, characterized by light industry (foodstuffs, leather products, clothes, shoes, furniture) and commonly derived from handicrafts, was more consumer-oriented than in other countries of Latin America. The result was a less capital intensive manufacturing sector.

Capital formation experienced a new decreasing trend in the 1960s that was associated with the stagflation. Another construction boom occurred in the 1970s. It was a pronounced cycle that, as in other periods, ended with a deep dive in the investment rate (the 1982's crisis). In general, the 1980s were a period of anemic growth and huge difficulties in the capital formation. Economic activity increased during the 1990s but with low investment rates (close to 15 per cent) that were consistent with the growing specialization in services with low capital requirements. The economy suffered another negative impact during the crisis of the first years of the $21^{\text {st }}$ century but, since 2003 , the investment rate recovered significantly to reach levels close to 20 per cent.

Figure 5

Fixed investment rate (current prices; in percentage)

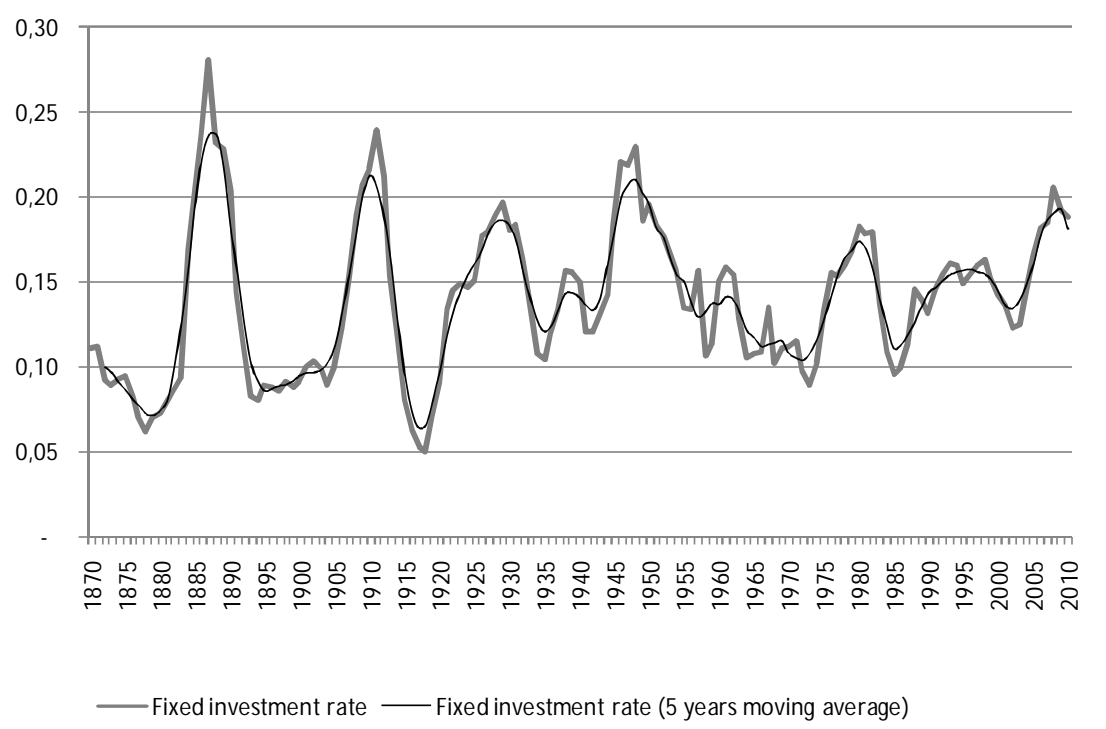

Source: See Appendix.

Therefore, in terms of stylized facts, Uruguay presented its most intensive investment push during the "construction of the economy" and the export-led growth era. The 
imports substitution industrialization -with the transition periods of the 1920s-1930s and the 1960s- was accompanied by a progressive de-capitalization process and it is not until the 1970s that this long-run tendency is reversed. However, this recovery has been slow, and even at the beginning of the $21^{\text {st }}$ century it is not absolutely clear if the economy has entered into a new trajectory. In terms of institutional quality -at least as reflected in the enforcement of contracts indicator- the improvements have been cyclical and seem to reflect the "life cycle" of each development phase.

\subsection{Growth, capital accumulation and contract enforcement: an econometric exercise}

Following Clague et al. (1999) and Prados de la Escosura and Sanz (2006 and 2009) we estimate a structural model to provide an answer to our question about the relation between quality of contract enforcement and economic performance. We undertake an exercise similar to that of the latter authors based on a system of simultaneous equations and employ the seemingly unrelated regression method (SUR) that solves the problems of contemporary correlation between residuals in a system of equations increasing estimation efficiency.

Our specification builds on a conventional growth model -Barro (1991), Ross and Renelt (1992), Mankiw et al. (1992)- that includes specific equations for the direct growth determinants. First we estimate a growth regression in which the dependent variable is the level of real GDP per worker (the number of workers have been approximated by the economically active population), and the right-hand-side variables are the growth of physical capital (measured by the rate of variation of the capital stock), the rate of variation of the economically active population as an indicator of labor force growth and the rate of enrollment in the education system -primary and secondary- representing the growth of human capital.

Then, we estimate a set of three equations which endogenize each explanatory variable from the growth equation (capital stock, economically active population and enrollment), allowing at the same time for more complex interactions and the possibility of indirect effects on growth. We estimate an equation in which physical capital growth depends on the usual macroeconomic determinants quoted in the literature -the real interest rate and the growth of real GDP per worker (lagged) (see for instance Mankiw 2006)- and other variables that can explain the investment decisions, such as the relative price of capital goods, the dependency ratio and the CIM. We expect a negative effect of the real interest rate and the relative price of capital on capital growth but a positive relation between the latter and GDP growth. In relation to the effect of the dependency ratio on capital accumulation, following the life-cycle hypothesis we expect a negative relation. People save during their "active" years but have negative saving during childhood and when they become old and retire. That means that when the dependency rate is high there should be less saving available to finance investment. ${ }^{17}$ Finally, our main focus is on the effect of CIM, which is expected to be positive on capital accumulation, which means that the quality of contract enforcement is a key determinant on investment.

\footnotetext{
${ }^{17}$ This is true if capital does not move internationally. Strikingly, it has been shown that international capital mobility is much more limited than predicted by theory, even between open and stable economies, an empirical regularity known as the Feldstein-Horioka puzzle (Apergis and Tsoumas 2009).
} 
In the third equation the explanatory variable is the (variation in) economically active population as a proxy of the labour force growth. The macroeconomic determinants of labour force include structural factors (policy and legal determinants, demographic and cultural factors, level of education and technological progress), cyclical factors (labour demand has an impact on labour supply) and accidental factors (wars, strikes, natural disasters; see more details in ILO 2011). We represent this broad set of independent variables with the lagged GDP (as the labour demand proxy), the dependency rate (to represent demographic factors) and enrollment (as a proxy of the education level).

Finally, the last equation with enrollment as the dependent variable represents the human capital accumulation of the economy. Since people invest more on human capital as life expectancy and the formal education period becomes longer, human capital in the country rises. Since human capital investment is related to economic conditions of countries, levels of human capital investment happen to be positively correlated with levels of economic activity (Bildirichi et al. 2008). We represent these relations in a simplistic way considering as independent variables the GDP (per worker) lagged (logarithmic transformation) and the dependency ratio.

The set of equations are the following:

GDP per worker $_{t}=\alpha_{0}+\alpha_{1} \frac{\Delta \text { Capital }}{\text { Capital }_{t-1}}+\alpha_{2} \frac{\Delta E A P}{E_{A P}-1}+\alpha_{3}$ Enrollment $_{t}+\varepsilon_{t}$

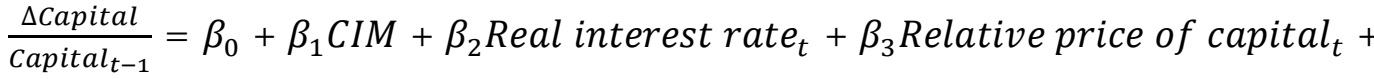

$$
\begin{aligned}
& \beta_{4} \text { Dependency rate }_{t}+\beta_{5} \frac{\Delta G D P \text { per worker }}{\text { GDP per worker } t-1}+v_{t}
\end{aligned}
$$

Enrollment $_{t}=\delta_{0}+\delta_{1}$ Dependency rate $_{t}+\delta_{2} G D P_{t-1}+\omega_{t}$

The main statistics for the key variables of the model are shown in Table 2. 
Table 2. Descriptive statistics of the variables (1870-2010)

$\begin{array}{lrrrrr} & \text { Mean } & \text { Standard Deviation } & \text { Minimum } & \text { Maximum Number } \\ \text { GDP per worker (in logs) } & 11,90 & 0,43 & 11,28 & 12,75 & 141 \\ \text { GDP (in logs) } & 18,32 & 1,12 & 16,24 & 20,15 & 141 \\ \text { Stock of capital (rate of variation) } & 0,03 & 0,03 & -0,02 & 0,13 & 140 \\ \text { Economically active population (rate of variation) } & 0,02 & 0,01 & 0,00 & 0,05 & 140 \\ \text { Enrollment (in logs) } & -0,28 & 0,84 & -1,92 & 1,05 & 141 \\ \text { Real interest rate } & 22,14 & 26,29 & -46,47 & 109,66 & 141 \\ \text { Relative price of capital goods } & 0,87 & 0,15 & 0,56 & 1,31 & 141 \\ \text { Dependency rate } & 0,70 & 0,13 & 0,56 & 0,96 & 141 \\ \text { CIM } & 0,68 & 0,07 & 0,44 & 0,79 & 141 \\ \text { Openess } & 0,30 & 0,10 & 0,16 & 0,65 & 141 \\ \text { Financial depth } & 0,27 & 0,13 & 0,08 & 0,58 & 141\end{array}$

The econometric results of the SUR model for the period 1870-2010 are presented in Table 3. Model (a) runs the four equations as described above (equations i to iv). Model (b) adds the effect of openness on growth and on capital accumulation and financial depth (ratio of money supply to GDP) in the latter as a robustness test for the results (Model b, columns 1 to 4).

The first column (Model a, column 1) shows that per worker GDP relates positively and significantly to capital accumulation, enrolment rate and the size of labor force. Regarding the change in capital stock equation (column number 2), it confirms theoretical predictions by displaying significant positive coefficients for the rate growth of per worker GDP, and shows a significant negative coefficient for the relative price of capital goods; the real interest rate is not statistically significant. One of our key findings is that capital accumulation depends on the quality of contract enforcement as captured by the CIM indicator, with the expected positive coefficient.

Lagged GDP presents positive and significant effects on labour force variation (column 3 ) and enrollment (column 4) showing the importance of the level of activity on the labor supply and the accumulation of human capital. In addition, enrollment plays a negative and significant role on labour force because both activities "compete" to some extent for active people's time.

Finally, the equation for dependency rate (column 4) deserves some specific comments. The estimated coefficients are positive and statistically significant in the cases of physical capital accumulation, labour force and enrollment. Theoretically, the influence of dependency rate on capital accumulation should be negative but the evidence about this hypothesis has not been conclusive in the empirical literature (Keho 2012; Loayza et al. 2000). The evolution of the dependency rate was decreasing in Uruguay from the end of the $19^{\text {th }}$ century to the first decade of the $21^{\text {th }}$ century but this evolution incorporated two opposite forces. Whereas the part of the dependency rate corresponding to young people decreased steadily (with a slowing down in the 1950s-1960s) the rate corresponding to old people increased without a break from the 1880s. The social security system was early implemented in Uruguay (see Azar et al. 2009) but it was not capable to extend the services to a broad proportion of the population and the retirement and pension incomes were low and usually insufficient to maintain the previous lifestyle. In consequence, a structural feature of Uruguayan labour force was the high participation of senior adult workers - usually in informal terms- to complement the personal incomes 
and, in facts, it meant the breakdown of the straightforward age-savings pattern..

Table 3. Econometric results seemingly unrelated regression model (SUR) 1870-2010

\begin{tabular}{|c|c|c|c|c|c|c|c|c|}
\hline VARIABLES & $\begin{array}{c}1) \\
\text { GDP per worker } \\
\text { (in logs) } \\
\end{array}$ & $\begin{array}{c}\text { Model (a) } \\
(2) \\
\begin{array}{c}\text { Capital stock (rate } \\
\text { of variation) }\end{array}\end{array}$ & $\begin{array}{c}\text { (3) } \\
\text { EAP (rate of } \\
\text { variation) }\end{array}$ & \begin{tabular}{c|}
$(4)$ \\
Enrollment \\
$(\operatorname{logs})$ \\
\end{tabular} & $\begin{array}{c}(1) \\
\text { GDP per } \\
\text { worker (in } \\
\operatorname{logs} \text { ) }\end{array}$ & $\begin{array}{c}\text { Mode } \\
\text { (2) } \\
\text { Capital stock } \\
\text { (rate of } \\
\text { variation) } \\
\end{array}$ & $\begin{array}{l}\frac{1 \text { (b) }}{(3)} \\
\text { EAP (rate of } \\
\text { variation) }\end{array}$ & $\begin{array}{c}(4) \\
\text { Enrollment } \\
(\operatorname{logs})\end{array}$ \\
\hline GDP per worker growth (t-1) & & $\begin{array}{l}0.116 * * * \\
{[0.0323]}\end{array}$ & & & & $\begin{array}{l}0.122 * * * * \\
{[0.0317]}\end{array}$ & & \\
\hline Real interest rate & & $\begin{array}{c}-7.67 \mathrm{e}-05 \\
{[0.000109]}\end{array}$ & & & & $\begin{array}{c}-4.09 \mathrm{e}-05 \\
{[0.000108]}\end{array}$ & & \\
\hline Relative price of capital & & $\begin{array}{c}-0.0314 * * \\
{[0.0153]}\end{array}$ & & & & $\begin{array}{c}-0.0382 * * \\
{[0.0153]}\end{array}$ & & \\
\hline Dependency rate & & $\begin{array}{c}0.0612 * * * \\
{[0.0227]}\end{array}$ & $\begin{array}{c}0.0688 * * * \\
{[0.00973]}\end{array}$ & $\begin{array}{c}0.786 * * * \\
{[0.230]}\end{array}$ & & $\begin{array}{l}0.0535 * * \\
{[0.0229]}\end{array}$ & $\begin{array}{c}0.0633 * * * \\
{[0.00989]}\end{array}$ & $\begin{array}{c}0.784 * * * \\
{[0.241]}\end{array}$ \\
\hline CIM & & $\begin{array}{c}0.0955^{* * *} \\
{[0.0324]}\end{array}$ & & & & $\begin{array}{c}0.0780 * * \\
{[0.0339]}\end{array}$ & & \\
\hline Capital stock (rate of variation) & $\begin{array}{c}1.994 * * * \\
{[0.374]}\end{array}$ & & & & $\begin{array}{c}1.662 * * * \\
{[0.359]}\end{array}$ & & & \\
\hline EAP (rate of variation) & $\begin{array}{c}6.932 * * * * \\
{[1.551]}\end{array}$ & & & & $\begin{array}{c}4.233 * * * \\
{[1.501]}\end{array}$ & & & \\
\hline Enrollment (logs) & $\begin{array}{l}0.578 * * * \\
{[0.0217]}\end{array}$ & & $\begin{array}{l}-0.00642 * \\
{[0.00329]}\end{array}$ & & $\begin{array}{c}0.512 * * * \\
{[0.0235]}\end{array}$ & & $\begin{array}{c}-0.00646^{*} \\
{[0.00334]}\end{array}$ & \\
\hline GDP $(\log s)(t-1)$ & & & $\begin{array}{l}0.00472 * \\
{[0.00280]}\end{array}$ & $\begin{array}{l}0.815^{* * * *} \\
{[0.0279]}\end{array}$ & & & $\begin{array}{c}0.00417 \\
{[0.00285]}\end{array}$ & $\begin{array}{c}0.817 * * * \\
{[0.0292]}\end{array}$ \\
\hline Openess & & & & & $\begin{array}{c}0.531^{* * * *} \\
{[0.139]}\end{array}$ & $\begin{array}{c}0.00373 \\
{[0.0298]}\end{array}$ & & \\
\hline Financial Depht & & & & & & $\begin{array}{c}0.0639 * * * \\
{[0.0231]}\end{array}$ & & \\
\hline Constant & $\begin{array}{l}11.87 * * * \\
{[0.0301]}\end{array}$ & $\begin{array}{l}-0.0519^{*} \\
{[0.0295]}\end{array}$ & $\begin{array}{l}-0.117 * * \\
{[0.0556]}\end{array}$ & $\begin{array}{c}-15.73^{* * *} \\
{[0.657]}\end{array}$ & $\begin{array}{c}11.76^{* * * *} \\
{[0.0498]}\end{array}$ & $\begin{array}{l}-0.0479 \\
{[0.0310]}\end{array}$ & $\begin{array}{c}-0.103 * \\
{[0.0566]}\end{array}$ & $\begin{array}{c}-15.77 * * * \\
{[0.689]}\end{array}$ \\
\hline Observations & 139 & 139 & 139 & 139 & 139 & 139 & 139 & 139 \\
\hline R-squared & 0.879 & 0.210 & 0.652 & 0.960 & 0.897 & 0.288 & 0.654 & 0.960 \\
\hline
\end{tabular}

Overall these results may be compared to those in Prados de la Escosura and Sanz (2009) for Argentina. In particular we highlight the positive relation of real per capita GDP with investment and enrollment rates, and the positive role played by CIM on capital accumulation. However, those authors find that the effect of CIM on investment is not contemporaneous but with a five-year lag. Despite this difference, the evidence confirms the relevance of the enforcement of contracts on the capital accumulation in the River Plate, which has been a repeatedly proposed but seldom tested explanations of the deficient long-run performance of the region.

When we include the effect of other control variables in the estimation our previous results remain largely unchanged (Table 3 , model b, columns 1 to 4 ). We consider the possible influence of openness on growth and on the variation of capital stock and the incidence of financial depth on the latter. Evidence shows that openness is positively related to economic growth, in line with the small size of the economy and a long history of participation in the commodity international markets. Openness is not important to explain investment but financial depth is positively and significantly correlated with capital accumulation. This is evidence of the relevance of the credit markets to finance de formation of physical capital.

Our theoretical foundation led us to consider that the influence of contract enforcement on economic activity operated through the pace of capital accumulation. However, it is legitimate to wonder if it may have a direct influence on growth, as it captures one of the key components of "institutional quality" that have been argued to promote growth. We undertake exercises similar to those presented in Table 3 but now adding the CIM as an independent variable in the growth equation (see Table 4, models $\mathrm{c}$ and d). All our previous results remain unchanged and the CIM indicator shows statistically significant 
coefficients in the capital accumulation equation and GDP growth, but with positive and negative signs respectively.

Table 4. Econometric results seemingly unrelated regression model (SUR) 1870-2010. Testing CIM on growth.

\begin{tabular}{|c|c|c|c|c|c|c|c|c|}
\hline \multirow[b]{2}{*}{ VARIABLES } & \multicolumn{4}{|c|}{ Model (c) } & \multicolumn{4}{|c|}{ Model (d) } \\
\hline & $\begin{array}{c}\text { (1) } \\
\text { GDP per worker } \\
\text { (in logs) } \\
\end{array}$ & $\begin{array}{c}\text { (2) } \\
\text { Capital stock } \\
\text { (rate of } \\
\text { variation) } \\
\end{array}$ & $\begin{array}{c}\text { (3) } \\
\text { EAP (rate of } \\
\text { variation) } \\
\end{array}$ & \begin{tabular}{c|}
$(4)$ \\
Enrollment \\
$(\operatorname{logs})$ \\
\end{tabular} & $\begin{array}{c}\text { (1) } \\
\text { GDP per worker } \\
\text { (in logs) } \\
\end{array}$ & $\begin{array}{c}(2) \\
\text { Capital stock } \\
\text { (rate of } \\
\text { variation) } \\
\end{array}$ & $\begin{array}{c}\text { (3) } \\
\text { EAP (rate } \\
\text { of } \\
\text { variation) } \\
\end{array}$ & $\begin{array}{c}(4) \\
\begin{array}{c}\text { Enrollment } \\
(\operatorname{logs})\end{array} \\
\end{array}$ \\
\hline GDP per worker growth (t-1) & & $\begin{array}{l}0.116^{* * * *} \\
{[0.0319]}\end{array}$ & & & & $\begin{array}{c}0.125 * * * \\
{[0.0314]}\end{array}$ & & \\
\hline Real interest rate & & $\begin{array}{c}-6.20 \mathrm{e}-05 \\
{[0.000107]}\end{array}$ & & & & $\begin{array}{c}-2.97 \mathrm{e}-05 \\
{[0.000108]}\end{array}$ & & \\
\hline Relative price of capital & & $\begin{array}{c}-0.0332 * * \\
{[0.0151]}\end{array}$ & & & & $\begin{array}{c}-0.0403 * * * \\
{[0.0152]}\end{array}$ & & \\
\hline Dependency rate & & $\begin{array}{c}0.0630 * * * \\
{[0.0226]}\end{array}$ & $\begin{array}{c}0.0678 * * * \\
{[0.00975]}\end{array}$ & $\begin{array}{c}0.804 * * * \\
{[0.227]}\end{array}$ & & $\begin{array}{c}0.0534 * * \\
{[0.0228]}\end{array}$ & $\begin{array}{c}0.0625^{* * *} \\
{[0.00990]}\end{array}$ & $\begin{array}{c}0.787 * * * \\
{[0.240]}\end{array}$ \\
\hline CIM & $\begin{array}{c}-0.531 * * * \\
{[0.158]}\end{array}$ & $\begin{array}{l}0.116 * * * \\
{[0.0329]}\end{array}$ & & & $\begin{array}{c}-0.531 * * * \\
{[0.149]}\end{array}$ & $\begin{array}{c}0.0914 * * * * \\
{[0.0340]}\end{array}$ & & \\
\hline Capital stock (rate of variation) & $\begin{array}{c}2.488 * * * \\
{[0.374]}\end{array}$ & & & & $\begin{array}{c}2.182 * * * * \\
{[0.360]}\end{array}$ & & & \\
\hline EAP (rate of variation) & $\begin{array}{c}6.189^{* * * *} \\
{[1.504]}\end{array}$ & & & & $\begin{array}{l}3.460 * * \\
{[1.450]}\end{array}$ & & & \\
\hline Enrollment (logs) & $\begin{array}{l}0.583 * * * \\
{[0.0212]}\end{array}$ & & $\begin{array}{c}-0.00646 \text { ** } \\
{[0.00329]}\end{array}$ & & $\begin{array}{l}0.515 * * * \\
{[0.0227]}\end{array}$ & & $\begin{array}{l}-0.00645^{*} \\
{[0.00335]}\end{array}$ & \\
\hline GDP $(\log s)(t-1)$ & & & $\begin{array}{c}0.00465^{*} \\
{[0.00280]}\end{array}$ & $\begin{array}{l}0.817 * * * \\
{[0.0275]}\end{array}$ & & & $\begin{array}{c}0.00407 \\
{[0.00285]}\end{array}$ & $\begin{array}{l}0.818 * * * \\
{[0.0290]}\end{array}$ \\
\hline Openess & & & & & $\begin{array}{c}0.558^{* * * *} \\
{[0.135]}\end{array}$ & $\begin{array}{l}-0.00171 \\
{[0.0297]}\end{array}$ & & \\
\hline Financial Depht & & & & & & $\begin{array}{c}0.0585^{* * *} \\
{[0.0230]}\end{array}$ & & \\
\hline Constant & $\begin{array}{c}12.23 * * * \\
{[0.112]}\end{array}$ & $\begin{array}{c}-0.0658^{* * *} \\
{[0.0298]}\end{array}$ & $\begin{array}{c}-0.115 * * \\
{[0.0557]}\end{array}$ & $\begin{array}{c}-15.78^{* * * *} \\
{[0.649]}\end{array}$ & $\begin{array}{c}12.11 * * * \\
{[0.110]}\end{array}$ & $\begin{array}{c}-0.0523 * \\
{[0.0311]}\end{array}$ & $\begin{array}{c}-0.101 * \\
{[0.0567]}\end{array}$ & $\begin{array}{c}-15.78 * * * \\
{[0.686]}\end{array}$ \\
\hline Observations & 139 & 139 & 139 & 139 & 139 & 139 & 139 & 139 \\
\hline R-squared & 0.881 & 0.214 & 0.653 & 0.960 & 0.900 & 0.289 & 0.654 & 0.960 \\
\hline
\end{tabular}

Are these results contradictory? Not necessarily. They actually direct attention to the argument proposed by Acemoglu and Johnson (2005) that the "institutions" that may influence performance need to be unpacked and each examined carefully before assuming direct and straightforward effects. In particular, they distinguish contracting institutions from property rights when it comes to elucidating how institutions affect performance. Our results lead us to accept the pertinence of the CIM indicator as a proxy of the quality of contract enforcement and we find evidence that it is significant and positively related with investment. However, institutionalist theory does not suggest that it should directly influence growth rates because it is not enough to catch the diverse dimensions of the institutional quality that potentially can influence the evolution of economic activity. Our results highlight the specificity of the institutional arrangements to explain the economic performance and the importance of identifying particular indicators to explain different economic processes.

We also explored with alternative estimations methods, samples, and variable definitions to check if our results are robust. SUR estimates with two equations (equation 1 and 2) or simple OLS regressions for each of the four first equations (equation 1 to 4), generate essentially the same results for the main variables, so it seems that our conclusions are robust to other estimation procedures. In addition, we estimate the model for the period 1912-2010, considering that some of our key series, mainly CIM and capital stock, might be less reliable before the second decade of the $20^{\text {th }}$ century. The main results do not 
differ. $^{18}$

\section{Concluding remarks}

Institutions and their quality are central concepts in the recent development and institutional economics literatures. Our hypothesis is that deficient contract enforcement has affected physical capital formation and, in consequence, indirectly has had an adverse effect on Uruguay's long-term growth performance.

To test our hypothesis, we first review the main concepts and the approaches to define and measure the quality of contract enforcement. Second, we consider one measure that has the advantage of being measurable in the long run and it depending on subjective judgments; that is, we consider the "contract intensive money" (CIM) indicator to represent one of the more important dimensions of institutional quality. Then, we examine the long term series (from 1870 to 2010) and discuss them in light of the most accepted interpretations about development and institutions in Uruguay, and of the comparison with Argentina. We find that the trajectory of the indicator matches the informed intuitions and some scholarly work about stages in Uruguay's institutional evolution in the long term. Using our long series for the CIM indicator, and extending key macroeconomic variables backwards to 1870 , we estimate a structural model to explore the plausibility of our hypothesis. The estimations, based on the "seemingly unrelated regressions" method (SUR), suggest that poor contract enforcement played a significant role at the origins of Uruguay's long-run relative decline, by depressing capital accumulation.

We obtain three main results at the conceptual, empirical and historic-analytical levels. Conceptually, we demonstrate that the enforcement of contracts, which is one of the main dimensions of institutional quality assumed to affect aggregate performance, presents long-run consequences on the evolution of capital accumulation and, indirectly, on economic growth. However, empirically there does not seem to exist a direct positive effect of contract enforcement on growth, which supports the argument by Acemoglu and Johnson (2005) on the need to differentiate contracting institutions from property rights institutions, and testing their specific causal channels, when it comes to clarifying how institutions affect on economic performance.

Finally, we demonstrate -as different studies about Uruguayan long run growth have argued- that dimensions of institutional quality are relevant to explain the Uruguayan backwardness. The results are in line with findings from a similar study for Argentina, and highlight the development relevance of "investing" in enhancing the enforcement of contracts or, equivalently, in reducing the costs and increasing the efficiency of access to the justice system or to other formal and informal mechanisms to adjudicate cases quickly and consistently. 18 There are not meaningful changes either if we use a depreciation rate of $8 \%$ instead of $5 \%$, for the
capital stock estimation using the MIP method. 


\section{References}

Aaron, J. (2000) "Growth and institutions: A review of the Evidence", World Bank Research Observer, 15(1): 99-135.

Aboal, A., Noya, N., Rius, A. (2012) "A systematic review on the evidence of the impact on investment rates of changes in the enforcement of contracts", London: EPPI-Centre, Social Science Research Unit, Institute of Education, University of London.

Acemoglu, D., Johnson, S. (2005) "Unbundling institutions", Journal of Political Economy, 113 (5): 949-995.

Acevedo, E. (1933) Anales de la Universidad. Tomo III, Casa A Barreiro y Ramos, Montevideo.

Acevedo, E. (1934) Anales de la Universidad. Tomo V, Casa A Barreiro y Ramos, Montevideo.

Álvarez, J., Bértola, L., Porcile, G. (2007) Primos ricos y empobrecidos. Crecimiento, distribución del ingreso e instituciones en Australia-Nueva Zelanda vs ArgentinaUruguay. Editorial Fin de Siglo, Montevideo.

Álvarez, J., Bértola, L. (2012) "So Similar, So Different: New Zealand and Uruguay in the World Economy", In: Lloyd C, Metzer J, Sutch, R. (eds.): Settler Economies in World History, Brill, Ch. 17, in print (http://www.brill.nl/settler-economies-world-history).

Álvarez, J., Bilancini, E., Dalessandro, S., Porcile, G. (2010) "Agricultural Institutions, Industrialization and Growth: The Case of New Zealand and Uruguay", Explorations in Economic History 48(2):151-168.

Álvarez, J., Willebald, H. (2011) "Agrarian income distribution, land ownership systems, and economic growth: settler economies during the First Globalization", $5^{\text {tas }}$ Jornadas de Historia Económica, Asociación Uruguaya de Historia Económica, Montevideo, November.

Antía, F. (2005) "La economía uruguaya desde el restablecimiento de la democracia. 19852000", In: Instituto de Economía, El Uruguay del Siglo XX. La Economía, Editorial Banda Oriental, Montevideo: 123-162.

Antía, F. (1986) "Endeudamiento externo, crisis financiera y política económica (1979-1983)", SUMA, 1 (1): 59-96, October, Montevideo.

Apergis, N., Tsoumas, C. (2009) "A survey of the Feldstein-Horioka puzzle: what has been done and where we stand", Research in Economics, 63: 64-76.

Arnábal, R., Bertino, M., Fleitas, S. (2011) "Una revisión del desempeño de la industria en Uruguay entre 1930 y 1959", Documento de Trabajo, 02/11, Instituto de Economía, Facultad de Ciencias Económicas y de Administración, Universidad de la República, Montevideo.

Arocena, E., Graziani, C. (1987) "El Ciclo Económico en el Uruguay entre 1866 y 1930. Investigaciones sobre la aplicación de una metodología para su cuantificación", Segundas Jornadas Anuales de Economía, noviembre, Banco Central del Uruguay, Montevideo.

Astori, D. (2001) "Estancamiento, desequilibrios y ruptura 1955-1972", In Instituto de Economía, El Uruguay del siglo XX. La economía, Banda Oriental, Montevideo: 65-94.

Azar, P., Bertino, M., Bertoni, R., Fleitas, S., García Repetto, U., Sanguinetti, C., Sienra, M., Torrelli, M. (2009) De quiénes, para quiénes y para qué. Las finanzas públicas en el Uruguay del siglo XX. Editorial Fin de Siglo, Montevideo, Uruguay.

Banco Central del Uruguay (1994) Boletín Estadístico, 169, Diciembre, Montevideo.

Banco Central del Uruguay (1989) Producto e Ingreso Nacionales. Montevideo. 
Banco Central del Uruguay (1994): Boletín Estadístico, 169, Diciembre, Montevideo.

Banco Central del Uruguay (1980) Indicadores de la actividad económico-financiera, Diciembre, Montevideo.

Banco Central del Uruguay (1976) Producto e Ingreso Nacionales. Actualización de las Principales Variables. División Asesoría Económica y Estudios, Montevideo.

Banco Central del Uruguay (1971) Series estadísticas monetarias y bancarias. Departamento de Investigaciones Económicas del Banco Central del Uruguay. Agosto, Montevideo.

Banco de la República Oriental del Uruguay (1965) Cuentas Nacionales, Montevideo.

Banerjee, S., Oetzel, J., Ranganathan, R. (2006) "Private Provision of Infrastructure in Emerging Markets: Do Institutions Matter?", Development Policy Review, 24 (2): 175202.

Baptista, B., Bértola, L. (1999) "Uruguay 1870-1913: Indicadores de Comercio Exterior", Segundas Jornadas de Historia Económica, Asociación Uruguaya de Historia Económica, Montevideo.

Barro, R. (1991) "Economic growth in a cross section of countries", Quarterly Journal of Economics, 106: 407-443.

Bergara, M., Zipitría, L. (2003) "Una visión institucional de la legislación de bancarrota", In: Bergara, M. (ed) Las reglas de juego en Uruguay, Trilce, Montevideo.

Berkowitz, D., Pistor, K., Richard, J. F. (2003) "Economic Development, Legality, and the Transplant Effect", European Economic Review, 47 (1): 165-195.

Bertino, M., Bertoni, R., Tajam, H., Yaffé, J. (2005) La economía del Primer Batllismo y los años veinte: Historia Económica del Uruguay. Tomo III, Editorial Fin de Siglo, Montevideo.

Bertino, M., Bertoni, R., Tajam, H., Yaffé, J. (2001) "La larga marcha hacia un frágil resultado 1900-1955", In Instituto de Economía, El Uruguay del siglo XX. La economía, Ediciones Banda Oriental, Montevideo: 9-63.

Bertino, M., Tajam, H. (1999) El PBI de Uruguay 1900-1955. Instituto de Economía, Facultad de Ciencias Económicas y de Administración, Universidad de la República, Montevideo.

Bértola, L. (2008) "An Overview of the Economic History of Uruguay since the 1870s", In: Whaples $\mathrm{R}$ (ed) EH.Net Encyclopedia, March 16, http://eh.net/encyclopedia/article/Bertola.Uruguay.final

Bértola, L. (2005) "A 50 años de la Curva de Kuznets: Crecimiento y distribución del ingreso en Uruguay y otras economías de nuevo asentamiento desde 1870", Investigaciones en Historia Económica, 3: 135-176.

Bértola, L. (1991) La industria manufacturera uruguaya 1913-1961: un enfoque sectorial de su crecimiento, fluctuaciones y crisis. Facultad de Ciencias Sociales de la Universidad de la República - Centro Interdisciplinario de Estudios sobre el Desarrollo Uruguay, Montevideo, Uruguay.

Bértola, L., Porcile, G. (2000) "Argentina, Brasil, Uruguay y la economía mundial: una aproximación a diferentes regímenes de convergencia y divergencia", In: Bértola L (ed) Ensayos de Historia Económica. El Uruguay y la región en la economía mundial 1870-1990, Trilce, Montevideo, pp. 53-90.

Bértola, L. and Collab. (2000) "Salarios, distribución del ingreso y aprendizaje en escenarios de convergencia y divergencia entre el Cono Sur y la economía mundial", In: Bértola, L. (ed) Ensayos de Historia Económica. Uruguay y la región en la economía mundial 1870-1990, Trilce, Montevideo, pp. 91-119.

Bértola, L., Camou, M., Maubrigades, S., Melgar, N. (2010) "Human Development and Inequality in the 20th Century: the Mercosur Countries in a comparative perspective", In: Salvatore, R., Coatsworth, J., Challú, A. (eds) Living Standards in Latin American 
History. Height, Welfare and Development, 1750-2000, Harvard University Press.

Bértola, L., Calicchio, L., Camou, M., Porcile, G. (1999) "Southern Cone Real Wages Compared: A Purchasing Power Parity Approach to Convergence and Divergence Trends,1870-1996", Documento de Trabajo, 44, Programa de Historia Económica y Social, Facultad de Ciencias Sociales, Universidad de la República, Montevideo.

Bértola, L., Calicchio, L., Camou, M., Rivero, L. (1998) El PBI Uruguayo 1870-1936 y otras estimaciones. Programa de Historia Económica, Facultad de Ciencias Sociales, Universidad de la República, Montevideo.

Bittencourt, G., Bértola, L. (2005) "Veinte años de Democracia sin Desarrollo Económico", In: Caetano, G. (Director) 20 años de Democracia. Uruguay 1985-2005. Miradas múltiples, Taurus, Montevideo.

Bildirici, M., Sunal, S., Aykac Alp, E., Orcan, M. (2008) "Determinants of Human Capital Theory, Growth and Brain Drain: An Econometric Analysis for 77 Countries", Applied Econometrics and International Development, Vol. 5-2.

Bonino, N., Román, C., Willebald, H. (2012) "PBI y estructura productiva en Uruguay: revisión de series históricas y propuesta metodológica", Documento de Trabajo, 05/12, Instituto de Economía, Facultad de Ciencias Económicas y de Administración, Universidad de la República, Uruguay.

Brunetti, A., Kisunko, G., Weder, B. (1998) "Credibility of Rules and Economic Growth. Evidence from a Worldwide Survey of the Private Sector", World Bank Economic Review, 12 (3): 353-384.

CEPAL (2006) "Población Económicamente Activa, América Latina y el Caribe", Observatorio Demográfico, Year 1, No2.

CEPAL - CELADE (2000) "América Latina: Población por años calendario y edades simples 1995-2005", Boletín Demográfico, No. 66, July, Population Division.

Clague, C., Keefer, P., Knack, S., Olson, M. (1999) "Contract-Intensive Money: Contract Enforcement, Property Rights, and Economic Performance", Journal of Economic Growth, 4 (2):185-211.

Clarke, G. (2001) "How the Quality of Institutions Affects Technological Deepening in Developing Countries", Working Paper Series, 2603, The World Bank.

Cungu, A., Swinnen, J. F. M. (2003) "Investment and Contract Enforcement in Transition: Evidence from Hungary", LICOS Discussion Paper, 2003/1, LICOS-Centre for Transition Econ. Katholieke Universiteit Leuven.

Dao, M. (2008) "The Impact of Investment Climate Indicators on Gross Capital Formation in Developing Countries", Journal of Developing Areas, 42(1): 155-163.

Devarajan, S., Easterly, W. R., Pack, H. (2001) "Is Investment in Africa Too Low or Too High?", Policy Research Working Paper, 2519. The World Bank, Washington.

Djankov, S., La Porta, R., Lopez-de-Silanes, F., Shleifer, A. (2008) "Debt Enforcement Around the World", Journal of Political Economy, 116(6): 1105-1149.

Djankov, S., La Porta, R., Lopez-de-Silanes, F., Schleifer, A. (2003) "Courts", Quarterly Journal of Economics, 118(2): 453-517.

Dollar, D., Easterly, W.R. (1999) "The Search for the Key: Aid, Investment and Policies in Africa", Journal of African Economies, 8 (4):546-77.

Errea, E., Peyrou, J., Secco, J., Souto, G. (2011) "Transformaciones en el agro uruguayo", Universidad Católica del Uruguay, Montevideo.

Fleitas, S., Román, C. (2010) "Evolución de la población económicamente activa en el siglo XX: un análisis de la estructura por sexo, edad y generaciones", Boletín de Historia Económica, Asociación Uruguaya de Historia Económica, 9, Montevideo. 
Fleitas, S., Rius, A. (2010) "Determinantes de la inversión en Uruguay", IV Jornadas de Investigación, Instituto de Economía, Facultad de Ciencias Económicas y Administración, Universidad de la República, Montevideo.

Finch, H. (2005) La Economía Política del Uruguay Contemporáneo. 1870-2000. Ediciones de la Banda Oriental, Montevideo.

Hamish, R., Streeter, D., Swinnen, J. (2000) "How Private Contract Enforcement Mechanisms Can Succeed Where Public Institutions Fail: The Case of Juhocukor a.s.", Agricultural Economics, 23 (2000):253-265.

ILO (2011) "Estimates and Projections of the Economically Active Population: 1990-2020. Methodological description", International Labour Organization, October. http://laborsta.ilo.org/applv8/data/EAPEP/v6/ILO_EAPEP_methodology_2011.pdf, November $15^{\text {th }}, 2011$.

Jacob, R. (1983) El Uruguay de Terra (1931 - 1938). Ediciones de la Banda Oriental, Montevideo.

Jacob, R. (1981) Uruguay 1929-1938: Depresión ganadera y desarrollo fabril. Fundación de Cultura Universitaria, Montevideo.

Jacob, R. (1977) El Uruguay en la crisis de 1929: Algunos indicadores económicos. Fundación de Cultura Universitaria, Montevideo.

Kaufmann, D., Kraay, A., Mastruzzi, M. (2004) "Governance Matters IV: Governance Indicators for 1996-2004", The World Bank, Washington DC.

Keefer, P. (2004) "A Review of The Political Economy of Governance: From Property Rights to Voice", Policy Research Working Paper Series, 3315, The World Bank, Washington DC.

Keho, Y. (2012) "Does dependency rate really impede savings? Some Sub-Saharan African evidence", Journal of African Studies and Development, 4(3): 69-80, April.

Knack, S., Keefer, P. (1995) "Institutions and Economic Performance: Cross-Country Tests Using Alternative Institutional Measures", Economics and Politics, 7: 207-227.

La Porta, R., Lopez-de-Silanes, F., Shleifer, A., Vishny, R.W. (1997) "Legal Determinants of External Finance", The Journal of Finance, 52(3):1131-1150.

Levine, R. (1998) "The Legal Environment, Banks and Long-Run Economic Growth", Journal of Money, Credit and Banking, 30 (3): 596-613.

Lin, C., Lin, P., Song, F. (2010) "Property Rights Protection and Corporate R\&D: Evidence from China", Journal of Development Economics, 93: 49-62.

Loayza, N., Schmidt-Hebbel, K., Serven, L. (2000) "What Drives Private Saving Across the World?", Policy Research Working Paper, 2309, The World Bank.

Maddison, A. (2003) Historical Statistics of the World Economy: 1-2008 AD. OECD, Paris.

Mankiw, G. (2006) Macroeconomía. Antoni Bosch editor, Sexta edición.

Mankiw, W., Romer, D., Weil, D. (1992) "A contribution to the empirics of economic growth", Quarterly Journal of Economics, 107(3): 407-437.

Mitchell, B. R. (1993) International Historical Statistics: The Americas 1750-1988, MacMillan Publishers Ltd, England.

Monge-Naranjo, A. (2009) "Entrepreneurship and Firm Heterogeneity with Limited Enforcement", Annals of Finance 5, no. 3 (June 1): 465-494.

Nahum, B. (2007) Estadísticas Históricas del Uruguay. 1900-1950. Tomo I: Población y Sociedad, Política, Educación, Estado. Departamento de Publicaciones, Universidad de la República, Montevideo.

Nahum, B. (1993) Manual de Historia del Uruguay. 1830-1903. Tomo 1, Ediciones de la Banda Oriental, Montevideo.

North, D. (1990) Institutions, Institutional Change and Economic Performance. Cambridge University Press, Cambridge. 
Notaro, J. (2001) "La batalla que ganó la economía. 1972-1984", In: Instituto de Economía, El Uruguay del Siglo XX. La Economía, Editorial Banda Oriental-Instituto de Economía, Montevideo, pp. 95-121.

Notaro, J. (1984) La Política Económica en el Uruguay. 1968-1984. Ediciones de la Banda Oriental-Centro Interdisciplinario de Estudios sobre el Desarrollo Uruguay, Montevideo, Uruguay.

Noya, N., Pereira, M., Prieto, G. (2003) "Crecimiento y Capital Humano en Uruguay: 19401999", Mimeo, Montevideo.

Obstfeld, M., Taylor, A. (2003) "Sovereign risk, credibility and the gold standard: 1970-1913 versus 1925-1931", The Economic Journal, 113: 241-275, April.

Oddone, G. (2010) El Declive. Una Mirada de la Economía de Uruguay el Siglo XX. Librería Linardi y Risso, Montevideo.

Pande, R., Udry, C.R. (2005) "Institutions and Development: A View from Below", Center Discussion Papers. Economic Growth Center, Yale University, New Haven, USA.

Pang, J., Wu, H. (2009) "Contract enforcement and the allocation of capital", Department of Economics, University of Alberta.

Pellegrino, A. (2001) "Un ensayo de estimación de la población del Uruguay entre 1885-1963", Facultad de Ciencias Sociales, Universidad de la República, mimeo.

Prados de la Escosura, L., Rosés, J. R. (2008) "Long-run Estimates of Physical Capital in Spain,1850-2000", Working Papers in Economic History, 08-07, Universidad Carlos III de Madrid.

Prados de la Escosura, L., Sanz, I. (2009) "Contract Enforcement, capital accumulation, and Argentina's long-run decline", Cliometrica, 3:1-26.

Prados de la Escosura, L., Sanz, I. (2006) "Contract Enforcement and Argentina's LongRun Decline", Economic History and Institutions Series Working Paper, 06-06, Departamento de Historia Económica e Instituciones, Universidad Carlos III, Madrid.

Raja, A., Schaefer, H. (2007) "Are Inventories a Buffer Against Weak Legal Systems? A Cross- Country Study", KYKLOS, 60 (3):415-439.

Rama, M. (1990) "Crecimiento y Estancamiento Económico en Uruguay", In: Blömstrom M, Meller, P. (eds) Trayectorias Divergentes: comparación de un siglo de desarrollo económico latinoamericano y escandinavo. CIEPLAN-Hachette, Santiago de Chile.

Rama, M. (1991) "El país de los vivos: un enfoque económico", SUMA, 6(11): 7-36, Montevideo.

Rehme, G. (2011) "Endogenous Policy and Cross-Country Growth Empirics", Scottish Journal of Political Economy, 58(2): 262-296.

Rodrik, D. (2000) "Institutions for high quality growth: What they are and how to acquire them", Studies in Comparative International Development, 35(3): 3-31.

Rodrik, D. (2005) "Why We Learn Nothing from Regressing Economic Growth on Policies", Harvard University, Boston, MA, mimeo.

Román, C., Willebald, H. (2011) "Apuntes metodológicos para la construcción de indicadores de inversión y de calidad institucional en el largo plazo: una propuesta para el caso uruguayo", II Jornadas Académicas, Facultad de Ciencias Económicas y de Administración, Universidad de la República, Montevideo. (Available by request from the authors hwillebald @iecon.ccee.edu.uy)

Román, C., Willebald, H. (2012) "Indicadores de inversión en el largo plazo: una propuesta para Uruguay (1870-2011)", Documento de Trabajo, 21/12, Instituto de Economía, Facultad de Ciencias Económicas y de Administración, Universidad de la República, Montevideo. 
Ross, L., Renelt, D. (1992) "A sensitivity analysis of cross-country growth regression", American Economic Review, 82: 942-963.

Sen, A. K. (1999) Development as Freedom. Anchor Books, New York.

Shirley, M. M. (2008) Institutions and Development. Edward Elgar, Cheltenham, UK and Northampton.

Siniscalchi , S. (2010) "Rol de las instituciones políticas en el Desarrollo. Apuntes para la construcción de un indicador de calidad institucional", Escuela de Verano de Historia Económica del Hemisferio Sur, Facultad de Ciencias Sociales, Universidad de la República. Montevideo.

Staats, J., Bowler, S., Hiskey, J. (2000) "Measuring Judicial Performance", Latin American Politics and Society, 47(4): 77-106.

Vaz, D. (1999) "Four Banking Crises Their Causes and Consequences". Revista de Economía, Segunda Época, VI(1), Junio: 29-334.

Visca, C. (1967) Emilio Reus y su época. Ediciones de la Banda Oriental, Montevideo.

Willebald, H., Bértola, L. (2012) "Uneven Development Paths Among Settler Societies, 18702000", In: Lloyd, C., Metzer, J., Sutch, R. (eds.) Settler Economies in World History, Brill, Ch. 4, in print (http://www.brill.nl/settler-economies-world-history).

Willebald, H. (2011) "Natural resources, settler economies and economic development during the first globalization: land frontier expansion and institutional arrangements", Departamento de Historia Económica e Instituciones, Universidad Carlos III de Madrid, URL: http://biblioteca.uc3m.es/uhtbin/cgisirsi/g5tdKk6Xgq/CCSSJJ/83570128/123

Willebald, H. (2007) "Desigualdad y especialización en el crecimiento de las economías templadas de nuevo asentamiento, 1870-1940", Revista de Historia Económica-Journal of Iberian and Latin American Economic History, 2/2007: 291-345.

Willebald, H. (2006) "Distribución y especialización productivo-comercial: Uruguay y las economías templadas de nuevo asentamiento, 1870-2000", Programa de Historia Económica y Social, Facultad de Ciencias Sociales, Universidad de la República, Uruguay, Master Dissertation,

Williams, A., Siddique, A. (2008) "The Use (and Abuse) of Governance Indicators in Economics: A Review", Economics of Governance, 9:131-175.

Williamson, J. (2000) "Land, labor and globalization in the pre-industrial third world", NBER, 7784.

Woodruf, C. (1998) "Contract Enforcement and Trade Liberalization in Mexico's Footwear Industry", World Development, 26(6): 979-991.

World Bank (2001) World Development Report 2002: Building Institutions for Markets. The World Bank, Washington DC.

World Bank (2006) Where is the Wealth of Nations? Measuring Capital for the 21 st Century. The World Bank, Washington, DC.

Zipitría, L. (2001) "Un análisis económico-institucional de los procedimientos concursales en el Uruguay", Conferencia Anual, LACEA, Montevideo.

Zurbriggen, C. (2006) Estado, empresarios y redes rentistas. Ediciones de la Banda Oriental, Montevideo. 


\section{Appendix}

\section{Sources}

Capital Stock

1870-2010: Román and Willebald (2012)

Contract Intensive Money (CIM) - Ratio of non- currency money to total money supply (M2)

1870-2010: Román and Willebald (2011)

Dependency Rate - Percentage of population below 15 and above 64 over populations ages 15 to $64(*)$

1950-2010: CEPAL - CELADE (2000)

1887-1950 Pellegrino (2001) based on data every five years, with linear interpolation.

1870-1887: Linear interpolation between data from Population Census in 1852 and Pellegrino (2001).

(*)We gratefully thanks Prof. Wanda Cabella for providing information and generously clear our doubts.

Economically Active Population (EAP) - Percentage of population over 14 years old that is either employed or actively seeking employment.

1997-2010: CEPAL (2006) (data every five years, with linear interpolation).

1908-1996: Fleitas and Román (2010) (1908-1949 data every five years with linear interpolations; 1950-1996 annual data).

1870-1907: Variation in labor force from Williamson (2000).

Enrollment - Primary and secondary enrollment: proportion of people between 5 and 18 years old in primary and secondary school.

2004-2010: own estimates from Ministerio de Educación y Cultura, Dirección de Educación, Uruguay, www.mec.gub.uy

1876 (for Primary) and 1900 (for Secondary) - 2003: student by level, Bértola et al. (2010).

1870-1899: estimation of secondary enrolment using an exponential function.

1870-1875: estimation of primary enrolment using a polynomial of third order function.

Financial Depth - Ratio of money supply (M2) to GDP

1870-2010: see sources of money supply and GDP.

Gross Domestic Product -GDP in Uruguayan pesos (at current and 2005 constant prices).

1870-2010: Bonino et al. (2012) based on Bértola et al. (1998), Bertino and Tajam (1999), Banco de la República Oriental del Uruguay (1965), Banco Central del Uruguay (1976, 1980, 1989, 1994 and data online www.bcu.gub.uy).

Inflation - Twelve month rate of inflation based on variation of consumer price index (CPI)

1937-2010: Instituto Nacional de Estadística, Uruguay, www.ine.gub.uy

1871-1936: Bértola et al. (1999). 
1870: Assumed the same as 1871.

Investment (Real)- Gross fixed capital formation at 2005 constant prices (in Uruguayan pesos)

1870-2010: Román and Willebald (2012).

Investment deflator - Ratio of nominal (current-price) to real (constant price) gross fixed capital formation.

1870-2010: see sources for investment rate and investment at constant prices.

Investment rate - Investment ratio to GDP.

1870-2010: Román and Willebald (2012)

Lending interest rate - Twelve month interest rate on bank loans to the private sector 2010: Banco Central del Uruguay, data on line www.bcu.gub.uy

1955-2009: Fleitas and Rius (2010).

1898-1954: Own estimations made by Carolina Román and Henry Willebald following the same strategy as Bertino et al. (2005: 329). Lending interest rate is based on the ratio between interest revenues and the interest-bearing assets of the Banco República using information from the bank records.

1872-1897: Obstfeld and Taylor (2003).

1870-1871: Assumed the same rate as 1872.

Money Supply (M2)

1870-2010: Román y Willebald (2011) based on diverse sources such as Acevedo (1933; 1934); Arocena y Grazziani (1987); Banco Central del Uruguay (1971); Statistical Yearbooks; Boletines Estadísticos from Banco Central del Uruguay.

\section{Population}

1996-2010: Instituto Nacional de Estadística, www.ine.gub.uy.

1870-1995: data base from Programa de Historia Económica y Social, Facultad de Ciencias Sociales, Universidad de la República.

Per capita GDP growth - Annual growth rate of per capita gross domestic product at constant prices (in 2005 pesos).

1870-2010: see sources of GDP and Population.

Population by age group

1950-2010: United Nations, Department of Economic and Social Affairs, Population

Division, Population Estimates and Projections Section http://esa.un.org/unpd/wpp/unpp/panel_indicators.htm. Population by five-year age group.

1940-1945: Mitchell (1993), population by five-year age group.

1908 and 1909-1939: Fleitas and Román (2010), 1909-1939 population by five-year age group.

1870-1907: own estimates.

Openess - Exports plus Imports ratio to GDP.

Own elaboration based on the following sources

Exports and Imports of goods and services 
1970-2010: Banco Central del Uruguay, Balance of Payments (data online www.bcu.gub.uy).

1950-1970: Banco Central del Uruguay (1971).

Exports and imports of goods

1913-1950: Bértola (1991).

Exports

1870-1913: Baptista and Bértola (1999)

Imports

1900-1913: Finch (2005)

1870-1900: Acevedo $(1933,1934)$

We consider the level of the series that include goods and services and propose a retropolation of that level with the evolution of series that only include goods.

Real interest rate - Yearly lending interest rate adjusted by inflation rate as defined above

(lending interest rate +1$) /\left(\right.$ inflation $_{t}$ rate $\left._{t}+1\right)$

1870-2010: see sources for inflation and lending interest rate.

Relative price of capital goods - Investment deflator ratio to price consumption index 1870-2010: see sources for investment deflator and inflation. 